\title{
Raso Banagari: Ekspresi Sosial Perantau terhadap Pembangunan Kampung Halaman
}

\author{
Syamsurizaldi Syamsurizaldi, ${ }^{*}$ Annisa Aulia Putri, Miftahul Viona Sari, \\ Ridho Yoliandri \\ Jurusan Administrasi Publik, Fakultas Ilmu Sosial dan Ilmu Politik (FISIP), \\ Universitas Andalas, Padang - Indonesia
}

\begin{abstract}
Generally, emigrants have a deep interest in the condition of their hometown. In the Minang community, that sense is called "raso banagari", a sense of belonging to the nagari. One form of embodiments of raso banagari is to participate in the development of nagari, both directly and indirectly. Managing the participation of nagari emigrants in the Solok Regency, the Solok Regent made policy in the form of Regent Regulation Number 10 of 2017 concerning Collaboration between the Regional Government and the Nagari Government with Solok Emigrants. Solok Regency has 47 nagari emigrant organizations out of 70 nagari(s). This study aims to determine and analyze the form and level of emigrant participation in nagari development in Solok Regency. This research uses a combination of quantitative and qualitative methods. The results showed that the form of emigrant participation in the development of the nagari was mostly in the form of donations of money, ideas, and networking.
\end{abstract}

Pada umumnya perantau memiliki rasa cinta yang tinggi terhadap kampung halamannya. Dalam masyarakat Minang disebut "raso banagar", rasa turut memiliki nagari. Salah satu bentuk perwujudan raso banagari adalah ikut berpartisipasi dalam pembangunam nagari, baik secara langsung maupun tidak langsung. Dalam mengelola partisipasi perantau nagari yang ada di Kabupaten Solok, Bupati Solok membuat kebijakan berupa Peraturan Bupati Nomor 10 Tahun 2017 tentang Kerjasama Pemerintah Daerah dan Pemerintah Nagari dengan Perantau Kabupaten Solok Kabupaten Solok memiliki 47 organisasi perantau nagari dari 70 nagari yang ada. Penelitian ini bertujuan untuk mengetahui dan menganalisis bentuk dan tingkat partisipasi perantau dalam pembangunan nagari di Kabupaten Solok. Penelitian ini menggunakan metode gabungan antara kuantitatif dengan kualitatif. Hasil penelitian menunjukan bahwa bentuk partisipasi perantau dalam pembangunan nagari adalah sebagian besar berbentuk sumbangan uang, pemikiran, dan jejaring.

Keywords: emigrant; nagari development; participation; Solok

*Korespondensi Penulis: Syamsurizaldi Syamsurizaldi (syamsurizaldi@soc.unand.ac.id), Jurusan Administrasi Publik, Fakultas Ilmu Sosial dan Ilmu Politik (FISIP), Kampus Univesitas Andalas, Limau Manis Kecamatan Pauh, Kota Padang, Sumatera Barat 25175. 


\section{Pendahuluan}

Untuk dapat menjalankan amanat UndangUndang Nomor 6 Tahun 2014 tentang Desa, pembangunan desa dilaksanakan dengan melibatkan partisipasi masyarakat. Paradigma pembangunan yang sangat dikembangkan saat ini adalah paradigma pemberdayaan yang berinti pada partisipasi masyarakat. Masyarakat sebagai pelaku utama pembangunan, dan pemerintah merupakan intermediasi dan katalisator perencanaan pembangunan.

Partisipasi merupakan keterlibatan mental atau pikiran atau moral atau perasaan dalam situasi kelompok yang mendorong untuk memberikan sumbangan kepada kelompok dalam usaha mencapai tujuan serta turut bertanggung jawab terhadap usaha yang bersangkutan (Ahfan, Asrori, dan Sipahutar 2015; Melis, Muthalib, and Apoda 2016). Partisipasi masyarakat didasarkan pada kemauan masyarakat sendiri untuk ikut terlibat dalam kegiatan di desa. Hal ini dimaksudkan agar pembangunan yang dilakukan sesuai dengan kehendak dan kebutuhan masyarakat desa, yang dapat mendorong kemajuan desa. Karena pada dasarnya, masyarakat desa lebih mengetahui apa potensi yang dimiliki oleh desa (Mahayana 2013; Soleh 2017).

Beberapa penelitian sebelumnya menemukan bahwa partisipasi masyarakat menjadi salah satu faktor yang menentukan kesuksesan pembangunan di desa. Rendahnya partisipasi masyarakat akan menjadi permasalahan yang fatal dalam pembangunan desa (Rohman 2010) Ermayanti, Hendrawati, dan Zamzami (2018) mengatakan bahwa kehadiran masyarakat merupakan hal yang penting untuk menunjang keberhasilan pembangunan. Tanpa adanya partisipasi masyarakat, kegiatan pembangunan desa tidak akan berjalan dengan lancar. Hal ini juga sejalan hasil penelitian Latif yang menyimpulkan bahwa partisipasi berperan dengan sangat baik dalam pembangunan infrastruktur di Desa Timoreng (Latif et al. 2019) Semakin tinggi tingkat partisipasi masyarakat, menyebabkan semakin tingginya keberhasilan pembangunan di desa.

Alokasi dana desa sebagai implikasi dari UU Nomor 6 Tahun 2014 tentang Desa ternyata memberikan dampak positif dan negatif juga terhadap pembangunan nagari (desa). Menggunakan terminologi Indeks Desa Membangun (IDM) dalam mengukur tingkat kemajuan pembangunan desa, studi yang dilakukan oleh Kementerian Desa PDTT bersama 33 Perguruan Tinggi di Indonesia tentang evaluasi pemanfaatan dana desa, khususnya di Provinsi Sumatera Barat ditemukan bahwa terjadi peningkatan status IDM termasuk pada indikator sosial dan lingkungan. Indikator sosial yang diukur berdasarkan variabel sarana kesehatan, sarana pendidikan, permukiman, terdapat kecendrungan menuju lebih baik, terkecuali pada variabel modal sosial pada indikator rasa bergotong royong yang menurun. Ternyata, peningkatan ekonomi sangat berpengaruh terhadap modal sosial masyarakat yang bergeser dari relasi sosial menjadi relasi transaksional (segala sesuatu diukur dengan materi) (Ekaputra 2018:31). Penurunan rasa bergotong royong ini terjadi pada masyarakat yang berada di nagari, dan mungkin juga bisa terjadi pada masyarakat nagari yang ada di rantau (perantau).

Di Provinsi Sumatera Barat, tradisi yang berkembang pada masyarakat nagari adalah me- 
ncari kehidupan yang layak di luar nagari, atau disebut juga "marantau". Pada dasarnya merantau banyak dilakukan oleh kaum laki-laki. Merantau menurut Naim (1984) merupakan tipe khusus dari migrasi dengan konotasi budaya sendiri yang tidak mudah diterjemahkan ke dalam Bahasa Inggris ataupun Bahasa lainnya. Namun demikian, merantau setidaknya harus mengandung enam unsur pokok, yaitu meninggalkan kampung halaman; dengan kemauan sendiri; untuk jangka waktu yang lama; untuk mencari penghidupan, menuntut ilmu, atau mencari pengalaman; biasanya dengan maksud kembali pulang. Dengan demikian merantau merupakan lembaga sosial yang membudaya (dalam Putri 2018). Konsep merantau dianggap sebagai suatu hal yang menjanjikan harapan untuk masa depan dan kehidupan yang lebih baik, dikaitkan dengan konteks sosial ekonomi dan bukan konteks politik. Tujuan merantau sering dikaitkan dengan tiga hal, yaitu mencari ilmu, mencari pekerjaan (pangkat) dan mencari harta.

Marantau merupakan salah satu kearifan lokal masyarakat Sumatera Barat. Banyaknya kearifan lokal yang dimiliki oleh bangsa Indonesia menunjukkan kekayaan yang dimiliki masyarakat. Apabila hal tersebut dipelihara sebagai sebuah kemajemukan bangsa kita, maka ini merupakan harta yang tidak ternilai dan dapat digunakan sebagai alat atau modal dasar sebuah harmoni bangsa (Samiyono 2017).

Secara sosiologis, perantau masih dianggap sebagai masyarakat (anak nagari), walaupun secara administrasi sudah tidak terdaftar sebagai penduduk nagari. Oleh karena itu, perantau masih memiliki tanggung jawab atas kemajuan nagari-nya. Ketika nagari asalnya meraih sebuah prestasi, perantau ikut merasa bangga, kemudian apabila nagari asalnya mengalami musibah, perantau ikut bersedih dan turut membantu, dan jika mengalami sesuatu yang jelek, ikut menanggung malu. Oleh karena itu, di banyak nagari keterlibatan perantau dalam pembangunan nagari masih diharapkan oleh masyarakat di kampung halaman, dan bagi perantau sendiri ikut berperan menjadi sebuah panggilan dan kebanggaan sebagai anak nagari. Kemudian, perantau dianggap sebagai masyarakat yang memiliki pengetahuan dan material yang lebih dari masyarakat yang tinggal di nagari, sehingga diharapkan memberikan kontribusi terhadap pembangunan nagari. Oleh karena itu, ikatan yang kuat di antara perantau diharapkan mampu membangun jalinan komunikasi yang baik dengan nagari, dan dapat ikut terlibat dalam pembangunan nagari.

Kajian tentang kontribusi perantau asal Sumatera Barat telah dilakukan beberapa peneliti di antaranya penelitian Pristiyanilicia Putri (2018) yang menemukan bahwa perantau sangat berperan dalam upaya recovery kampung pasca gempa di Sumatera Barat 30 September 2009 dengan membangun sarana sosial dan sarana umum yang rusak seperti membangun surau, sekolah, masjid, rumah kerabat dan sebagainya.

Penelitian Annisa Aulia Putri (2019) menyatakan bahwa berdasarkan data pembangunan mulai tahun 2008-2016, persentase sumber pendanaan pembangunan paling banyak berupa swadaya masyarakat yang dikumpulkan dari perantau.

Penelitian Syamsurizaldi, Putri, dan Antoni (2019) menemukan bahwa perantau adalah salah satu aktor kunci yang ikut berkolaborasi 
dalam penyelenggaraan nagari rancak di Sumatera Barat. Besarnya perhatian perantau terhadap kemajuan kampung halamannya, ternyata berkontribusi terhadap kemajuan nagari. Oleh karena itu penelitian ini lebih lanjut mengkaji bentuk dan tingkatan partisipasi perantau dalam pembangunan nagari.

Kabupaten Solok merupakan salah satu kabupaten di Provinsi Sumatera Barat yang memiliki perantau yang cukup banyak. Berdasarkan data Bagian Kerjasama dan Rantau Sekretariat Daerah Kabupaten Solok tahun 2018, dari 74 nagari terdapat 47 nagari yang memiliki organisasi perantau yang tersebar pada 40 kota di Indonesia dan 6 di luar negeri yaitu Malaysia, Thailand, China, Australia, Belanda dan Perancis. Organisasi perantau di Kabupaten Solok tahun 2018 dapat dilihat pada Tabel 1.

Untuk dapat mengelola dan memaksimalkan partisipasi perantau, Bupati Solok menetapkan Peraturan Bupati Nomor 10 Tahun 2017 tentang Kerjasama Pemerintah Daerah dan Pemerintah Nagari dengan Perantau Kabupaten Solok. Regulasi ini dibuat sebagai payung hukum dalam pengelolaan potensi rantau dalam melakukan kerjasama untuk pembangunan daerah dan pembangunan nagari. Secara moral, perantau juga ikut bertanggung jawab dalam pembangunan nagari dan daerah, baik pembangunan fisik maupun nonfisik. Walaupun setelah adanya UU Desa Pemerintah lebih fokus dalam pengeloaan Dana Desa untuk pembangunan nagari, namun pengelolaan sumbangan dan batuan dari perantau belum menjadi perahatian secara khusus. Regulasi tentang penyelenggaraan Pemerintahan Desa yang menjadi turunan dari UU Nomor 6 Tahun 2014 juga tidak mengatur secara khusus tentang partisipasi perantau, karena keberadaan perantau merupakan keunikan suatu daerah dan tidak berlaku secara nasional. Berangkat dari latar belakang di atas, peneliti tertarik untuk meneliti tentang partisipasi perantau dalam pembangunan nagari di Kabupaten Solok sebelum dan setelah adanya Undang-Undang Desa.

Berdasarkan uraian latar belakang permasalahan di atas, dengan metode kualitatif dan kuantitatif (Sugiono 2006), tulisan ini mengupas bentuk dan tingkat partisipasi perantau dalam pembangunan nagari di Kabupaten Solok sebelum dan setelah adanya UU Desa. Selain itu tulisan ini juga mengulas implikasi kebijakan kerjasama Pemerintah Daerah, Pemerintah Nagari dan para perantau dalam pembangunan nagari di Kabupaten Solok.

\section{Bentuk Partisipasi Masyarakat dalam Pembangunan Nagari}

Dalam penyelenggaraan pemerintahan $n a-$ gari, diperlukan adanya partisipasi masyarakat. Menurut KBBI, partisipasi diartikan turut berperan serta di suatu kegiatan. Sedangkan menurut Suteng (2006) partisipasi merupakan mengambil bagian atau ikut serta atau berperan serta dalam suatu usaha bersama dengan orang lain untuk kepentingan bersama. Menurut Ruslan (2005) partisipasi adalah prinsip bahwa setiap orang memiliki hak untuk terlibat dalam pengambilan keputusan di setiap kegiatan penyelenggaraan pemerintahan. 
Tabel 1.

Nama Organisasi Perantau Nagari di Kabupaten Solok Tahun 2018

\begin{tabular}{|c|c|c|}
\hline No. & Nama Organisasi & Nagari \\
\hline 1. & Kerukunan Warga Tanjung Balik (KWARTAB) & Tanjung Balik \\
\hline 2. & Sulit Air Sepakat (SAS) & Sulit Air \\
\hline 3. & Ikatan Keluarga Paninjauan Sepakat (IKPS) & Paninjauan \\
\hline 4. & Ikatan Keluarga Talang dan Sungai Janiah (IKTAS)/Forum Masyarakat Nagari Talang (FMNT) & Talang/Sungai Janiah \\
\hline 5. & Kaperba & Bukit Tandang \\
\hline 6. & Persatuan Perantau Dilam & Dilam \\
\hline 7. & Persatuan Perantau Beringin Kuncir/Baringin Kuncir Sepakat & Kuncir \\
\hline 8. & Persatuan Perantau Bukit Bais (PPBB) & Bukit Bais \\
\hline 9. & Persatuan Warga Koto Baru (PERWAKO) & Koto Baru \\
\hline 10. & Ikatan Keluarga Besar Nagari Koto Laweh (IKLAS) & Koto Laweh \\
\hline 11. & Bukit Kandung Sepakat (BKS) & Bukit Kandung \\
\hline 12. & Ikatan Keluarga Tikalak (IKATIKA) & Tikalak \\
\hline 13. & Ikatan Keluarga Aripan/Himpunan Aripan Sepakat (HARKAT) & Aripan \\
\hline 14. & Ikatan Keluarga Guguk Sarai (IKGS) & Guguk Sarai \\
\hline 15. & Ikatan Keluarga Sungai Durian (IKASD) & Sungai Durian \\
\hline 16. & Ikatan Keluarga Pianggu (IKAPI) & Pianggu \\
\hline 17. & Ikatan Keluarga Muaro Paneh & Muaro Paneh \\
\hline 18. & Pantai Cermin Sepakat (PCS) & Pantai Cermin \\
\hline 19. & Ikatan Keluarga Gantung Ciri (IKGC) & Gantung Ciri \\
\hline 20. & Ikatan Keluarga Panyakalan (IKPP) & Panyakalan \\
\hline 21. & Ikatan Keluarga Pasilihan (IKPS) & Pasilihan \\
\hline 22. & Warga Nagari Sirukan (WARSI) & Sirukam \\
\hline 23. & Kerukunan Warga Kinari & Kinari \\
\hline 24. & Ikatan Keluarga Koto Hilalang (IKK) & Koto Hilalang \\
\hline 25. & Ikatan Keluarga Selayo (IKS) & Selayo \\
\hline 26. & Ikatan Keluarga Tanjung Bingkung (IKAT) & Tanjung Bingkung \\
\hline 27. & Ikatan Keluarga Saok Laweh (IKSAL) & Saok Laweh \\
\hline 28. & Ikatan Keluarga Saniangbaka (IWS) & Saniang Baka \\
\hline 29. & Ikatan Keluarga Koto Sani (IKKS) & Koto Sani \\
\hline 30. & Ikatan Keluarga Singkarak (IKS) & Singakarak \\
\hline 31. & Ikatan Keluarga Kacang (IKKA) & Kacang \\
\hline 32. & Keluarga Masyarakat Sumani & Sumani \\
\hline 33. & Persatuan Warga Tanjung Alai (PERWATA) & Tanjung Alai \\
\hline 34. & Ikatan Keluarga Perantau Muaro Paneh (IKPM) & Muaro Paneh \\
\hline 35. & Ikatan Keluarga Cupak (IKC) & Cupak \\
\hline 36. & Labuah Panjang Saiyo (LPS) & Labuan Panjang \\
\hline 37. & Ikatan Keluarga Garabak Data (IKAGARDA) & Garabak Data \\
\hline 38. & Urang Lolo & Lolo \\
\hline 39. & Ikatan Keluarga Besar Koto Anau (IPKA) & Koto Gadang Koto Anau \\
\hline 40. & Ikatan Keluarga Limau Lunggo & Limau Lunggo \\
\hline 41. & Ikatan Warga Supayung & Supayang \\
\hline 42. & Persatuan Perantau Sungai Abu Sepakat (PESSAS) & Sarik Alahan Tigo \\
\hline 43. & Ikatan Keluarga Lembah Gumanti (IKLG) & Air Dingin \\
\hline 44. & Ikatan Keluarga Indudur (IKPI) & Indudur \\
\hline 45. & Ikatan Warga Taruang Taruang (IWARTA) & Taruang-Taruang \\
\hline 46. & Persatuan Keluarga Paninggahan (PKP) & Paninggahan \\
\hline 47. & Anak Nagari Aia Luo Sepakat (Anagalu) & Air Luo \\
\hline
\end{tabular}

Sumber: Bagian Kerjasama dan Rantau Setda Kabupaten Solok (2019) 
Partisipasi merupakan bagian yang tidak terpisahkan dari pembangunan, sehingga seluruh lapisan masyarakat akan memperoleh hak dan kekuatan yang sama untuk menuntut atau mendapat bagian yang adil dari manfaat pembangunan (Ningrum 2014). Keith Davis juga memberikan pendapat mengenai konsep partisipasi yaitu keterlibatan pikiran dan emosi seseorang dalam situasi kelompok yang memberikan semangat untuk menyokong kepada tujuan-tujuan kelompok dan mengambil bagian tanggung jawab kelompok itu sendiri (Henryk 2013). Keith Davis (dalam Sastropoetro 1986) mengemukakan jenisjenis partisipasi masyarakat dalam pembangunan yaitu: 1) pikiran (psychological participation), 2) tenaga (physical participation), 3) pikiran dan tenaga (psychological and physical participation), 4) keahlian (participation with skill), 5) barang (material participation) dan uang (money participation).

Lebih lanjut Davis juga menjabarkan jenisjenis partisipasi dalam bentuk: 1) konsultasi dalam bentuk jasa, 2) sumbangan spontan berupa uang atau barang, 3) mendirikan proyek yang sifatnya berdikari dan dananya berasal dari sumbangan individu/ instansi yang berasal dari luar lingkungan tertentu (dermawan/pihak ketiga), 4) mendirikan proyek yang bersifat swadaya dan dibiayai oleh seluruh komunitas (biasanya diputuskan oleh rapat komunitas, rapat desa yang menentukan anggarannya), 5) sumbangan dalam bentuk kerja, biasanya dilakukan oleh tenaga ahli setempat, 6) aksi massa, 7) mengadakan pembangunan di kalangan keluarga desa sendiri, 8) membangun proyek komuniti yang bersifat otonomi, 9) membangun proyek komunitas yang bersifat otonomi.
Merantau telah menjadi budaya pada masyarakat Sumatera Barat. Dalam KBBI, merantau berarti berlayar atau mencari penghidupan di tanah rantau atau pergi ke negeri lain untuk mencari penghidupan, ilmu, dan sebagainya. Berdasarkan kajian kemasyarakatan, merantau merupakan orang yang meninggalkan territorial asal dan menempati territorial baru. Budaya merantau pada masyarakat Sumatera Barat memiliki karakteristik tersendiri. Merantau dijadikan ajang untuk belajar tentang kehidupan. Merantau bagi masyarakat Sumatera Barati dapat meningkatkan martabat seseorang di tengah lingkungan adat. Merantau umumnya menjadi keharusan bagi setiap bujang di nagari, karena dengan membuktikan kesuksesannya di rantau, si bujang tersebut akan ikut sukses dalam berbagai hal yang menyangkut adat (Kato 2005).

Seberapa jauh pun seseorang merantau, masih termasuk masyarakat nagari, namun disebut dengan masyarakat perantau. Sebagai bagian dari masyarakat desa, perantau juga memiliki peran dalam melaksanakan pembangunan. Hal ini dikarenakan, pada umumnya para perantau memiliki kesuksesan yang lebih dari masyarakat di nagari, sehingga partisipasi perantau sangat diharapkan. Untuk dapat mengkoordinasi perantau, diperlukan adanya organisasi atau ikatan perantau. Organisasi inilah yang akan berkoordinasi dengan pemerintah nagari untuk melibatkan diri dalam proses pembangunan.

\section{Tingkat Partisipasi Masyarakat dalam Pembangunan}

Disamping bentuk, kajian tentang partisipasi masyarakat dalam pembangunan desa juga dapat dilihat dari tingkatan (level) partisipasi, karena banyak ahli mengkritisi bahwa bentuk partisipasi 
belum cukup untuk menjelaskan hakikat partisipasi yang sesungguhnya. Chouguill (2002) mencoba membedakan tingkat partisipasi dalam pembangunan mulai dari yang paling dominan peran masyarakat ke paling dominan peran pemerintah seperti diuraikan berikut ini: 1) empowerment, masyarakat mengendalikan pembangunan dan mempunyai kedudukan mayoritas atau kekuasaan yang dispesifikasikan dengan benar-benar pada badan pembuat keputusan formal, 2) partnership, masyarakat dan pemerintah berbagi tanggung jawab dalam perencanaan dan pengambilan keputusan proyek-proyek pembangunan, 3) conciliation, pemerintah memikirkan solusi yang akhirnya disahkan oleh rakyat dengan menunjuk beberapa wakil masyarakat sebagai kelompok penasihat atau badan pengambil keputusan, 4) dissimulation, rakyat didudukkan pada lembaga penasihat sebagai tukang stempel atau penandatangan yang bersifat formalitas belaka, 5) diplomation, pemerintah mencari pendapat masyarakat, melalui konsultasi, survey sikap, dengar pendapat, peninjauan lapangan, pertemuan dengan masyarakat, tetapi tidak ada jaminan pendapat dan idenya akan dipertimbangkan, 6) informing, menginformasikan hak, kewajiban dan pilihan-pilihan, tanpa negosiasi, 7) conspiration, tidak ada partisipasi sama sekali. 8) self-management, pemerintah tidak melakukan apapun untuk menyelesaikan persoalan lokal.

Proses pembangunan merupakan sebuah siklus dan memiliki tahapan-tahapan masingmasingnya. Menurut Adi (2001) partisipasi dalam pembangunan juga dapat dilihat dalam empat tahapan. Pertama, assesment, yaitu tahap mengidentifikasi masalah dan sumber daya yang dimiliki. Kedua, alternative program, yaitu tahap masyarakat mengajukan usulan program alter- natif dari permasalahan yang telah diidentifikasi pada tahap awal. Ketiga, tahap pelaksanaan program, yaitu program yang direncanakan dapat dilaksanakan. Masyarakat dapat berpartisipasi dalam bentuk tenaga dan materi. Keempat, tahap evaluasi, yaitu evaluasi yang dilakukan masyarakat terhadap pembangunan yang telah dijalankan.

Dalam penyelenggaraan pemerintahan desa berdasarkan UU Nomor 6 Tahun 2014, siklus dan tahapan pembangunan ini untuk jangka pendek dilaksanakan satu tahun dengan dokumen perencanaannya yaitu Rencana Kerja Pemerintah Desa (RKPD) yang akan menjadi rujukan dalam penyusunan APB Desa. Penyusunan RKPD dimulai dari dari proses assessment yaitu penggalian gagasan dari tingkat jorong, kemudian Musrenbang Nagari. Untuk jangka menengah dilaksanakan selama enam tahun dengan dokumen perencanaannya yaitu Rencana Pembangunan Jangka Menengah Desa (RPJM Desa). Jangka waktu enam tahun mengacu kepada masa jabatan kepala desa selama enam tahun. Prosesnya juga dimulai dari musyawarah desa dalam membahas RPJM Desa. Keberadaan partisipasi perantau pada hakikatnya dapat berkontribusi pada semua tahapan proses pembangunan di nagari.

\section{Bentuk Partisipasi Perantau dalam Pembangunan Nagari di Kabupaten Solok}

\section{Partisipasi dalam Bentuk Sumbangan Pikiran}

Undang-Undang Nomor 6 Tahun 2014 tentang Desa mengamanatkan masyarakat menjadi subjek pembangunan. Masyarakat diharapkan 
keterlibatannya dalam setiap tahap pembangunan. Hal ini supaya pembangunan dapat tepat sasaran dan sesuai dengan kebutuhan masyarakat. Partisipasi masyarakat ini dilakukan bukan hanya pada tahap pelaksanaan, tetapi dimulai dari perencanaan sampai evaluasi. Pada tahap perencanaan, masyarakat diharapkan menyampaikan ide dan gagasan terkait program pembangunan yang akan dilaksanakan satu tahun kedepan. Hal ini dilaksanakan pada Musyawarah Nagari (Musna) untuk membahas hal-hal yang bersifat strategis dengan melibatkan sebuah stakeholder di nagari. Musyawarah Nagari dilakukan sebelum dilaksanakannya Musyawarah Rencana Pembangunan (Musrenbang). Perantau, sebagai bagian dari masyarakat nagari juga di- libatkan dalam perencanaan, dalam artian sumbangan pikiran. Temuan di lapangan, terdapat beberapa bentuk sumbangan pikiran yang diberikan oleh perantau, yang diringkas dalam Tabel 2 .

Dari Tabel 2, terlihat bahwa sebagian besar perantau memberikan sumbangan ide melalui Whatsapp Group (WAG) dikarenakan akses jarak dan waktu yang tidak memungkinkan untuk memberikan sumbagan pikiran dengan hadir langsung. Pada Tabel 2 juga terlihat satu-satunya nagari yang perantaunya tidak memberikan sumbangan pikiran untuk pembangunan nagari, adalah Nagari Selayo Kecamatan Kubung. nagari Selayo memiliki organisasi perantau, yang setiap

Tabel 2.

Media Penyampaian Sumbangan Pikiran Perantau dalam Pembangunan Nagari

\begin{tabular}{|c|c|c|c|}
\hline No. & Nagari & Kecamatan & Media Sumbangan Pikiran \\
\hline 1. & Batang Barus & Gunung Talang & - Melalui kerabat yang ada di nagari \\
\hline 2. & Alahan Panjang & Lembah Gumanti & - Melalui Whatsapp Group (WAG) \\
\hline 3. & Sungai Durian & IX Koto Sungai Lasi & $\begin{array}{l}\text { - Melalui WAG, tidak dengan menghadiri } \\
\text { musyawarah } \\
\text { - Melalui kerabat yang ada di nagari }\end{array}$ \\
\hline 4. & Labuh Panjang & X Koto Diatas & $\begin{array}{l}\text { - Perantau hadir dalam musyawarah nagari } \\
\text { - Menyampaikan ide lewat pertemuan rutin } \\
\text { perantau dengan pemerintah nagari (bulanan dan } \\
\text { tahunan) } \\
\text { - Pulang basamo }\end{array}$ \\
\hline 5. & Selayo & Kubung & $\begin{array}{l}\text { - Perantau jarang memberikan sumbangan ide } \\
\text { kepada pemerintah nagari }\end{array}$ \\
\hline 6. & Paninggahan & Junjuang Sirieh & $\begin{array}{l}\text { - Melalui WAG } \\
\text { - Pulang basamo } \\
\text { - Melalui Mukernas PKP yang dilaksanakan secara } \\
\text { bergiliran di perantauan }\end{array}$ \\
\hline 7. & Sulit Air & X Koto Diatas & $\begin{array}{l}\text { - Melalui WAG } \\
\text { - Melalui Mukernas DPP SAS sekali dua tahun. } \\
\text { - Pada saat pemerintah nagari singgah ke rantau } \\
\text { - Pada saat perantau pulang basamo sekali dua } \\
\text { tahun }\end{array}$ \\
\hline
\end{tabular}

Sumber: Olahan Peneliti, 2019 
daerahnya memiliki nama yang berbeda. Tetapi, hubungan perantau dengan Pemerintah nagari tidak terjalin dengan baik. Hal ini dibuktikan dengan tidak ditemukannya sumbangan organisasi perantau dalam bentuk ide dan gagasan untuk Pembangunan nagari. Kondisi ini berbanding terbalik dengan Nagari Sulit Air, Kecamatan X Koto Diatas. Perantau Nagari Sulit Air sudah memiliki organsasi perantau yang tersebar di seluruh Indonesia dan luar negeri. Organisasi perantau di Sulit Air bernama SAS, yang memiliki Dewan Pengurus Pusat. Dalam tahap perencanaan pembangunan, pemerintah nagari yang biasanya diwakili oleh wali nagari menghadiri Musyawarah Kerja Nasional (Mukernas) bersama perantau. Mukernas dilakukan sebelum menyusun RAPBNag. Permintaan saran ini dilakukan oleh pemerintah nagari karena perantau secara legal tidak diperbolehkan untuk mengikuti Musrenbang. Kesempatan untuk mendapatkan ide dan saran bagi pengembangan pembangunan nagari juga didapatkan oleh pemerintah pada saat pemerintah nagari melakukan kunjungan ke tempat perantau serta pada saat para perantau pulang basamo.

Hal yang sama juga terjadi di Nagari Batang Barus dan Nagari Sungai Durian. Perantau di dua nagari ini menyampaikan ide melalui kerabat yang ada di nagari, untuk dapat disampaikan pada saat Musyawarah Nagari. Sedangkan di Nagari Labuah Panjang, organisasi perantau baru terbentuk pada tahun 2017, dan perantau yang dekat dengan nagari, seperti perantau di Sawah Lunto, Padang, dan sekitarnya menyampaikan ide dengan cara menghadiri Musyawarah Nagari. Perantau memiliki agenda pertemuan rutin satu kali sebulan, dan sumbagan ide juga dilakukan pada saat pertemuan tersebut.

\section{Partisipasi dalam Bentuk Tenaga}

Perantau merupakan masyarakat nagari yang tidak menetap di nagari. Secara administrasi bukan penduduk nagari, tetapi berasal dari nagari. Mereka disebut anak nagari. Perantau biasanya pulang pada saat ada acara-acara besar keagamaan, seperti lebaran ataupun pada saat libur. Karena sudah bermukim dan bekerja di daerah rantau, biasanya perantau hanya pulang sesekali dan dalam waktu singkat. Oleh karena itu perantau sangat jarang memberikan sumbangan tenaga dalam pembangunan. Tetapi, hal ini tidak menutup kemungkinan adanya partisipasi perantau dalam bentuk sumbangan tenaga.

Salah satu contoh perantau yang memberikan sumbangan dalam bentuk tenaga adalah perantau Nagari Labuh Panjang yang melakukan gotong royong rutin setiap minggu. Perantau yang bermukim tidak jauh dari nagari biasanya ikut terlibat dalam gotong royong tersebut. Berbeda dengan Nagari Selayo, walaupun ada gotong royong, masyarakat dan perantau jarang ikut dalam kegiatan tersebut. Hal ini karena adanya persepsi masyarakat bahwa setiap kegiatan di nagari sudah ada Dana Desa untuk membiayai, sehingga tidak perlu ada gotong royong. Sedangkan di lima nagari lainnya, sumbangan tenaga jarang dilakukan, dan hanya pada saat gotong royong.

\section{Partisipasi dalam Bentuk Barang dan Uang}

Pada umumnya, perantau memiliki "raso banagari" yang tinggi. Perantau akan memberikan sumbangan untuk pengembangan kampung halamannya berupa sumbangan materi, baik berupa barang maupun uang. Partisipasi dalam 
bentuk barang dan uang pada tujuh nagari di Kabupaten Solok, dijabarkan pada Tabel 3.

Pada Tabel 3 dapat dilihat bahwa pada umumnya sumbangan yang diberikan oleh perantau dalam bentuk uang. Hal ini disebabkan oleh faktor perantau yang tidak berada di nagari. pada beberapa nagari, uang yang sumbangkan tersebut digunakan untuk pembangunan fisik. Seperti yang terjadi di Nagari Paninggahan, Batang Barus dan Alahan Panjang. Ketiga nagari ini memberikan sumbangan dalam bentuk uang kepada nagari untuk melakukan pembangunan masjid, Selain itu, juga dikumpulkan sumbangan spontan untuk kegiatan-kegiatan yang ada di nagari, seperti khatam al-Qur'an, atau ketika terjadi kemalangan. Tidak berbeda jauh dengan ketiga nagari tersebut, Perantau Nagari Sungai Durian juga memberikan sumbangan uang kepada masyarakat melalui zakat, qurban di nagari, maupun sumbangan spontan untuk kegiatan-kegiatan yang dilaksanakan. Namun, sumbangan yang diberikan perantau di Nagari Sungai Durian tidak dipergunakan untuk melakukan pembangunan fisik. Hal ini dikarenakan menurut Sekretaris Nagari, pemerintah nagari sudah menganggarkan pembangunan tersebut.

Tabel 3.

Bentuk Sumbagan Barang dan Uang Rantau dalam Pembangunan

\begin{tabular}{|c|c|c|c|}
\hline No. & Nagari & Kecamatan & Bentuk Sumbangan \\
\hline 1. & Batang Barus & Gunung Talang & - Dana pribadi \\
\hline 2. & Alahan Panjang & Lembah Gumanti & - Sumbangan spontan \\
\hline 3. & Sungai Durian & IX Koto Sungai Lasi & $\begin{array}{l}\text { - luran perantau } \\
\text { - Sumbangan spontan } \\
\text { - Zakat } \\
\text { - Waqaf tanah } \\
\text { - Beasiswa }\end{array}$ \\
\hline 4. & Labuh Panjang & X Koto Diatas & $\begin{array}{l}\text { - Dana pribadi } \\
\text { - Sumbangan spontan dari organisasi } \\
\text { - Sumbangan ketika ada bencana } \\
\text { - Zakat dan Qurban }\end{array}$ \\
\hline 5. & Selayo & Kubung & $\begin{array}{l}\text { - Rumah singgah di Jakarta } \\
\text { - Dana Pribadi } \\
\text { - Ambulance }\end{array}$ \\
\hline 6. & Paninggahan & Junjuang Sirieh & $\begin{array}{l}\text { - Sumbagan spontan } \\
\text { - Networking } \\
\text { - Iuran untuk pembangunan gedung dan } \\
\text { bangunan milik nagari seperti Kantor Wali } \\
\text { Nagari dan Kantor Anak Nagari. }\end{array}$ \\
\hline 7. & Sulit Air & X Koto Diatas & $\begin{array}{l}\text { - Dana pribadi untuk berbagai pembangunan } \\
\text { fisik dan sarana nagari (kantor dan sarana } \\
\text { prasarana nagari) } \\
\text { - Beasiswa untuk mahasiswa } \\
\text { - Sumbangan spontan } \\
\text { - Pembangunan masjid } \\
\text { - Ambulance } \\
\text { - Motor pengagkut sampah }\end{array}$ \\
\hline
\end{tabular}

Sumber: Olahan Peneliti,2019 
Fenomena yang hampir sama terjadi di Nagari Labuah Panjang. Perantau memberikan sumbangan secara spontan untuk kegiatan-kegiatan yang ada di nagari. Misalnya terjadi kemalangan, perantau akan mengumpulkan uang untuk disalurkan kepada keluarga yang tertimpa kemalangan. Sedangkan untuk pembangunan fisik, belum menggunakan dana dari perantau.

Hal yang sedikit berbeda terjadi di Nagari Sulit Air. Nagari ini memiliki ikatan perantau yang kuat, sehingga dalam hal pembangunan, perantau ikut menyumbangkan dalam bentuk uang. Penggunaan uang tersebut disesuaikan dengan kebutuhan di nagari, dan pengelolaannya diserahkan penuh kepada masyarakat nagari. Selain dalam bentuk sumbangan kelompok, juga ada perantau yang memberikan sumbagan pribadi untuk pembangunan nagari. Sumbangan ini diberikan untuk pembangunan masjid, untuk pembangunan jembatan, yang sumbangannya atas nama pribadi. Namun, belum ditemukannya perantau yang memberikan sumbangan dalam bentuk barang di nagari ini.

Hal berbeda terjadi di Nagari Selayo, perantau tidak melakukan pembangunan di nagari, tetapi perantau membuat rumah singgah, yang digunakan untuk menampung masyarakat nagari yang pergi ke rantau tetapi tidak mempunyai tujuan. Selain itu, perantau menyumbang ke nagari atas nama sumbangan pribadi.

\section{Tingkat Partisipasi Perantau dalam Pembangunan Nagari di Kabupaten Solok}

Dari terdapat delapan tingkatan partisipasi masyarakat di negara-negara yang kurang berkembang (underdeveloped) sebagaimana di- kemukakan Chouguill (2002), berdasarkan temuan peneliti di lapangan, dari tujuh nagari yang diteliti, lima di antaranya tingkatan partisipasi perantau di nagari berada pada tingkatan partnership. Tidak ada satu pun dari nagari yang diteliti berada pada tingkatan empowernment.

Di Nagari Paninggahan sebelum melaksanakan pembangunan, pemerintah nagari bersama masyarakat di nagari melakukan musyawarah dan perencanaan. Dalam proses ini uniknya perantau tidak dilibatkan. Hasil dari dua kegiatan tersebut diinformasikan kepada perantau untuk melihat kesanggupan perantau dalam berpartisipasi terhadap program yang sedang dilakukan. Penentuan kesanggupan dari perantau dilakukan pada saat Musyawarah Kerja Nasional yang dilakukan satu kali dalam satu tahun.

Hal yang hampir sama juga dilakukan di Nagari Labuah Panjang. Namun perantau Nagari Labuah Panjang masih dilibatkan dalam musyawarah nagari. Selain itu, perantau juga melaksanakan pertemuan rutin dengan pemerintah nagari setiap bulan. Agenda yang dilakukan berupa arisan dan pemberian iuran wajib yang dipergunakan untuk sumbagan dan untuk uang sosial. Sedangkan komunikasi rutin yang berupa pemberitahuan dan konsultasi yang dilakukan pemerintah nagari dilakukan melalui aplikasi Whatsapp Group. Pembagian peran yang dilakukan sering kali ketika terjadi kebutuhan mendesak seperti bencana, dan kegiatan-kegiatan anak nagari, perantau akan memberikan sumbangan spontan untuk membantu, tanpa perlu dikoordinasi oleh Pemerintah nagari.

Di Nagari Sulik Air, partisipasi perantau juga berada pada tingkatan partnership. Dana yang diberikan oleh perantau merupakan pelengkap 
dari dana desa. Tahap perencanaan dilakukan oleh pemerintah nagari bersama dengan masyarakat di nagari, lalu disampaikan kepada perantau melalui forum resmi, kemudian perantau mengucurkan bantuan. Oleh karena itu, tidak terjadi tumpang tindih antara perantau dan pemerintah nagari, dan pembagian kewenangan menjadi jelas.

Sedikit berbeda dengan nagari-nagari sebelumnya, di Nagari Sungai Durian, partisipasi perantau berada pada tingkatan consiliation. Perantau tidak menghadiri musyawarah nagari, tetapi mereka mengusulkan kegiatan yang akan dilakukan melalui masyarakat yang di kampung. Perantau di Nagari Sungai Durian juga belum sampai pada tahap pembagian kewenangan dengan pemerintah nagari.

Kondisi yang lebih parah juga terjadi di Nagari Selayo. Perantau dengan pemerintah nagari kurang koordinasi, yang cenderung tidak sejalan. Perantau tetap merasa memiliki tanggung jawab untuk nagari, tetapi tidak dilakukan melalui koordinasi dengan pemerintah nagari. Kondisi ini diperparah oleh konflik yang terjadi antara Pemerintah nagari dengan Perantau.

\section{Implikasi Kebijakan Kerjasama Pemerintahan dan Pemerintahan Nagari dengan Perantau dalam Pembangunan Nagari di Kabupaten Solok}

Peraturan Bupati Kabupaten Solok Nomor 10 Tahun 2017 tentang Kerjasama Pemerintah Daerah dan Pemerintah Nagari dengan Perantau Kabupaten Solok dimaksudkan untuk memperjelas hubungan antara Pemerintah Daerah, Pe- merintah Nagari, dan Perantau yang ada di Kabupaten Solok. Kebijakan ini menjadi payung hukum untuk mengelola potensi perantau dalam melakukan kerja sama untuk pembangunan daerah dan pembangunan nagari.

Dengan dikeluarkannya kebijakan kerjasama ini, pemerintah daerah lebih mudah mendata dan menfasilitasi organisasi perantau nagari yang ada di Kabupaten Solok, yang dapat menunjang pelaksanaan pembangunan daerah dan nagari. Namun, kebijakan ini belum memiliki implikasi yang nyata. Pemerintah Nagari belum mampu mendata secara rinci dan rapi terkait partisipasi perantau. Partisipasi lebih sering dilakukan karena kesadaran moral perantau yang ingin membangun Nagari, tapi tidak diarsipkan oleh Pemerintah Nagari. Sehingga, seringkali data terkait partisipasi perantau sulit untuk ditemukan kecuali bukti fisik yang terlihat. Pada sebagian besar nagari yang diteliti, pada beberapa nagari sinergitas partisipasi perantau dengan perencanaan pembangunan nagari belum terlaksanakan sebagaimana diharapkan. Salah satu kendala dalam mengukur bentuk partisipasi perantau dalam pembangunan nagari, yaitu sumbangan atau dana dari perantau jarang dicatat sebagai bagian dari masukan berupa anggaran dalam pembangunan nagari.

Temuan lain dalam penelitian ini adalah Undang-Undang Nomor 6 Tahun 2014 tentang Desa tidak merubah bentuk partisipasi perantau dalam pembangunan. Hal ini dikarenakan, secara administratif pada umumnya perantau bukanlah bagian dari penduduk nagari. Jika merujuk pada Undang-Undang Desa, perantau bukan bagian dari kelompok masyarakat nagari yang harus 
diikutsertakan dalam kegiatan pembangunan nagari. Namun, partisipasi perantau didorong oleh rasa memiliki nagari yang tinggi. Hal ini salah satu faktor yang menyebabkan pada umumnya tingkatan partisipasi perantau pada umumnya cenderung partnership. Sejalan dengan penelitian (Syamsurizaldi et al. (2018), partisipasi perantau bisa mengisi ruang kosong pembangunan nagari, yaitu partisipasi pada kegiatan sosial dan pemberdayaan yang tidak bisa didanai melalui dana desa. Sehingga sinergitas antara pemerintah nagari dan perantau sangat diperlukan agar kegiatan pembangunan di nagari tidak hanya terfokus pada kegiatan pembangunan fisik, namun juga pada pemberdayaan masyarakat.

\section{Kesimpulan}

Perantau merupakan bagian yang tidak terpisahkan dalam pembangunan. Perantau tidak termasuk ke dalam penduduk nagari, tetapi merupakan bagian dari masyarakat nagari. Partisipasi perantau merupakan salah satu unsur penting untuk meningkatkan pembangunan $\mathrm{di}$ nagari. Partisipasi perantau mempunyai beberapa bentuk. Hasil temuan di lapangan, Partisipasi perantau di tujuh nagari di Kabupaten Solok lebih banyak dalam bentuk sumbangan dana. Namun, dalam bentuk sumbangan pikiran, perantau dilibatkan secara tidak langsung dan tidak dalam forum formal, seperti penyampaian melalui WAG ataupun melalui kerabat di nagari. Keterlibatan perantau di nagari juga dipengaruhi oleh faktor adanya hubungan yang baik antara pemerintah nagari dengan perantau.

Berdasarkan hasil analisis dan dan temuan peneltian dapat disampaikan beberapa saran dan rekomendasi terkait dengan partisipasi perantau dalam pembangunan nagari sebagai berikut: 1) Terhadap nagari yang belum memiliki organisasi perantau diharapkan peran pemerintah daerah memotivasi dan memfasilitasi wali nagari dan tokoh perantau untuk membentuk organisasi perantau nagari. Demikian juga terhadap organisasi perantau yang kurang aktif. 2) Sinkronisasi kegiatan pembangunan nagari dengan program kerja perantau perlu dilakukan agar pemanfaatan bantuan perantau dalam pembangunan nagari dapat lebih optimal dalam membantu kemajuan pembangunan nagari. Partisipsi perantau perlu dikembangkan ke dalam bentuk kegiatan pemberdayaan masyarakat terutama bagi keluarga miskin.

\section{Ucapan Terima Kasih}

Penelitian ini dibiayai melalui Dana DIPA FISIP Universitas Andalas TA 2019, sesuai dengan Surat Kontrak Nomor: 01/PL/SPK/PNP/FISIP-UNAND2019, tanggal 03 September 2019. Oleh karena itu pada kesempatan ini, kami dari Tim Peneliti menyampaikan ucapan terima kasih kepada Dekan dan Pimpinan FISIP Universitas Andalas beserta jajaran yang telah memberikan kesempatan untuk melaksanakan penelitian dan salah satu luarannya adalah artikel ini.]

\section{Daftar Pustaka}

Adi, Isbandi Rukminto. 2001. Pemberdayaan, Pengembangan Masyarakat, dan Intervensi Komunitas. Jakarta: Lembaga Penerbit Fakultas Ekonomi Universitas Indonesia.

Ahfan, Rahmawati, Asrori Asrori, dan Hotnier Sipahutar. 2015. "Implikasi Juara Lomba 
Desa pada Perkembangan Desa." Jurnal Bina Praja 07(04):297-305.

Chouguill, M. B. 2002. "A Letter of Community Participation for Under Development Countries." Habitat Intl 20(3):431-444.

Ekaputra, Erigas. 2018. Data dan Infromasi Manfaat Dana Desa di Provinsi Sumatera Barat. Badan Penelitian, Pengembangan, Pendidikan, Pelatihan dan Informasi Kementerian Desa, PDT dan Transmigrasi dan LPPM Universitas Andalas.

Ermayanti, Hendrawati, dan Lucky Zamzami. 2018. "Studi Partisipasi Masyarakat terhadap Pelaksanaan Program PNPM Mandiri di Sumatera Barat." Jurnal Antropologi: Isu-Isu Sosial Budaya 20(1):33-43.

Henryk, Stepanus. 2013. "Partisipasi Masyarakat dalam Pembangunan di Kelurahan Sungai Keledang Kecamatan Samarinda Seberang Kota Samarinda." eJournal Ilmu Pemerintahan FISIP Universitas Mulawarman 1(2):612-25.

Kato, Tsuyoshi. 2005. Adat Minangkabau dan Merantau dalam Perspektif Sejarah. Jakarta: Balai Pustaka.

Latif, Adam, Irwan Irwan, Muhammad Rusdi, Ahmad Mustanir, dan Muh Sutrisno. 2019. “Partisipasi Masyarakat dalam Pembangunan Infrastruktur di Desa Timoreng Panua Kecamatan Panca Rijang Kabupaten Sidenreng Rappang." Moderat:Jurnal Ilmiah Ilmu Pemerintahan 5(1):1-15.

Mahayana, Wayan. 2013. "Peran Kepala Desa dalam Meningkatkan Pembangunan Desa di Desa Bumi Rapak Kecamatan Kaubun Kabupaten Kutai Timur." eJournal Ilmu Pemerintahan 1(1).

Melis, Melis, Abd. Aziz Muthalib, dan Apoda Apoda. 2016. "Analisis Partisipasi Masya- rakat dalam Pembangunan Desa (Studi di Desa Wawolesea, Kecamatan Laloso, Kabupaten Konawe Utara)." Jurnal Ekonomi (JE) 1(1):99-405.

Naim, Mochtar. 1984. Merantau: Pola Migrasi Suku Minangkabau. Yogyakarta: Gadjah Mada University Press.

Ningrum, Harni Abrianti. 2014. "Partisipasi Masyarakat dalam Program Nasional Pemberdayaan Masyarakat Mandiri." eJournal Sosiatri-Sosiologi FISIP Universitas Mulawarman 2(3):1-13.

Putri, Annisa Aulia. 2019. "Partisipasi Perantau; Basamo Mambangun Nagari di Nagari Sungai Pua Kabupaten Agam." Jurnal Administrasi dan Kebijakan Publik 4(1):4254.

Putri, Pristiyanilicia. 2018. "Peranan Urang Rantau terhadap Pembangunan Masyarakat Nagari Pasca Gempa 30 September 2009." Hal. 497-502 in Seminar Nasional Royal (SENAR) 2018. Kisaran: Amik Royal.

Rohman, Nanang. 2010. "Implementasi Kebijakan Pembangunan Desa Dampaknya terhadap Koordinasi UPTD dalam Peningkatan Kinerja Pemerintahan Desa dan Efektivitas Pembangunan Desa." Jurnal Pembangunan dan Kebijakan Publik 1(1):30-36.

Ruslan, D. 2005. “Tata Pemerintahan yang Baik (Good Governance) dalam Pembangunan Daerah." Jurnal Kewarganegaraan 3(2): 185-203.

Samiyono, David. 2017. "Membangun Harmoni Sosial: Kajian Sosiologi Agama tentang Kearifan Lokal sebagai Modal Dasar Harmoni Sosial." JSW (Jurnal Sosiologi Walisongo) 1(2):195-206. 
Sastropoetro, Achmad Santoso. 1986. Partisipasi, Komunikasi, Persuasi dan Disiplin dalam Pembangunan Nasional. Bandung: Alumni.

Soleh, Ahmad. 2017. "Strategi Pengembangan Masyarakat Desa." Jurnal Sungkai 5(1):3252.

Sugiono. 2006. Metode Penelitian Kuantitatif, Kualitatif, dan $R \& D$. Bandung: Alfabeta.

Suteng, B. 2006. Pendidikan Kewarganegaraan Kelas XI. Jakarta: Erlangga.

Syamsurizaldi, Annisa Aulia Putri, Rozidateno Putri Hanida, dan Suherdian Antoni. 2018.
"Dampak Perkembangan Sumber Keuangan Nagari terhadap Inovasi Program dan Kegiatan Pembangunan Nagari di Kabupaten Solok Selatan Tahun 20132016." Jurnal Pembangunan Nagari 3(1):75-96.

Syamsurizaldi, Syamsurizaldi, Annisa Aulia Putri, dan Suherdian Antoni. 2019. "Model Collaborative Governance pada Nagari Rancak di Provinsi Sumatera Barat." Jurnal Pembangunan Nagari 4(1):99-121. 
This page intentionally left blank. 